\title{
ПЕРВЫЕ ПЕРИОДИЧЕСКИЕ ИЗДАНИЯ БОСНИИ И ГЕРЦЕГОВИНЫ ${ }^{1}$
}

\section{Аннотация:}

В 1865 г. в Сараеве открылась типография и начался выпуск первых газет в Боснийском вилайете. В статье идёт речь о периодических изданиях, которые выходили в Боснии и Герцеговине с 1866 по 1878 гг. («Боснийский вестник», «Босния», «Сараевский цветник», «Неретва»).

\section{Ключевые слова:}

Боснийский вилайет, типография, Игнатий Сопрон, Мехмед Шачир Куртчехаич, «Боснийский вестник», «Босния», «Сараевский цветник», «Неретва».

Abstract: K.V. MelchaKova "The first PERIOdicals of Bosnia AND HerZegovina".

In 1865 a printing house was opened in Sarajevo and in the Bosnia Vilayet the publication of the first newspapers began. The article deals with periodicals published in Bosnia and Herzegovina from 1866 to 1878: "Bosanski vjestnik", "Bosna", "Sarajevski cvjetnik", "Neretva".

\section{Keywords:}

The Bosnia Vilayet, the printing house, Ignatije Sopron, Mehmed Shachir Kurtchehaich, "Bosanski vjestnik", "Bosna", "Sarajevski cvjetnik", "Neretva".

$\mathbf{B}$ середине ХІХ столетия Босния и Герцеговина входили в состав ном славяне, которые являлись приверженцами разных вероисповеданий. Мусульмане, православные и католики воспринимали себя как отдельные народы, у каждого из них были свои особые традиции и культура ${ }^{2}$. В самом западном пограничном регионе Турции было много проблем разного характера, в том числе с грамотностью населения.

Вторая половина ХІХ столетия - время танзимата (мн. ч. от араб. слова «танзим» - упорядочение) в Османской империи 3 . В начале 1860-х годов начался процесс реформ в Боснии и Герцеговине. В 1865 г. эти области были объединены в Боснийский вилайет. Тогда же появились и первые боснийские газеты.

1 Работа выполнена при финансовой поддержке РФФИ (грант № 18-512-76004).

2 См.: Гильфердинг А.Ф. Босния, Герцеговина и Старая Сербия // Собрание сочинений А. Гильфердинга. Том третий. Босния и Герцеговина и Старая Сербия. СПб., 1873. С. 1-278.

3 См.: Еремеев Д.Е., Мейер М.С. История Турции в средние века и новое время. М., 1994. 
В национальной историографии вопрос о зарождении журналистики в Боснии и Герцеговине волновал исследователей, начиная со второй половины XX века, актуальным он остается и в наши дни

Перед тем как перейти к рассмотрению изданий Боснийского вилайета справедливо упомянуть журнал «Боснийский друг» ("Bosanski prijatelj") выпуск которого в 1850 г. был организован писателем, католическим монахом Иваном Франьо Юкичем (1818-1857). Вышло всего четыре номера: в 1850, 1851, 1861, 1870 гг. Все они печатались на латинице в хорватских землях. Первые два были изданы самим Юкичем, а вторые - на средства хорватской матицы ${ }^{6}$. Юкич пытался основать в Боснии типографию, но ему не удалось осуществить задуманного ${ }^{7}$

Открытие типографии и издание первых газет в самом регионе связаны с именем реформатора и одного из передовых людей своего времени Топал Шериф Осман-паши (1804-1874)․․ С 1861 по 1869 гг. он занимал пост генерал-губернатора (вали) Боснийского вилайета.

В 1860-е годы типографии создавались в разных частях Османской империи. Властями предписывалось выпускать официальные газеты, в которых публиковались законодательные акты. Кроме того, на местах должны были печатать учебную литературу. До этого момента во многие уголки Турции, в особенности на Балканы, учебники и периодические издания поступали из зарубежных стран․

Первая типография в Боснии появилась в 1865 г. Топал Шериф Османпаша пригласил из австрийского города Земун ${ }^{10}$ книгопечатника Игнатия Сопрона $(1821-1897)^{11}$. Он был родом из семьи торговцев, вырос в НовиСаде, где и изучил основы печатного дела. Некоторое время Сопрон работал в государственной типографии в Вене, затем в редакции газеты извест-

4 См., например: Пејановић Ђ. Штампа Босне и Херцеговине 1850-1941. Сарајево, 1949; Kruševac T. Bosansko-hercegovački listovi u XIX veku. Sarajevo, 1978; Ademović F. Prve novine i prvi novinari u Bosni i Hercegovini. Sarajevo, 1999; Dizdar S. Prvi Bošnjački novinar: Mehmed Šaćir Kurtćehajić (1844-1872) // Bosniaca. Casopis Nacionalne i univerzitetske biblioteke Bosne i Hercegovine. God. 17. Br. 17. (decembar 2012). S. 60-67; Eadem. Bibliografija sarajevskog cvjetnika: prilog povijesti knjige. Sarajevo, 2017; Бабић Б., ЈанићJ. Сопронова печатња. Бања Лука, 2016.

5 Cм.: Kruševac T. Bosansko-hercegovački listovi u XIX veku. S. 15-26.

6 Bosanski prijatelj. Sv. 1-4. 1850, 1851, 1861, 1870.

7 Ademović F. Prve novine i prvi novinari u Bosni i Hercegovini. S. 16

8 Koetschet J. Osman Pascha, der letzte grosse Wesier Bosniens und seine Nachfolger. Sarajevo, 1909; Мельчакова К.В. Осман-паша в погоне за прогрессом. К проблеме конструирования боснийской нации в Османской империи в 1861-1869 гг. // Вынужденное соседство - добровольное приспособление в дипломатических и межнациональных отношениях в Центральной, Восточной и Юго-Восточной Европе XVIII-XXI вв. Сборник статей. М.; СПб., 2017. С. 269-284.

9 Kruševac T. Bosansko-hercegovački listovi u XIX veku. S. 12.

10 Ныне район Белграда.

11 Подробнее об И. Сопроне см.: Kruševac T. Bosansko-hercegovački listovi u XIX veku. S. 29; Ademović F. Prve novine i prvi novinari u Bosni i Hercegovini. S. 103-105; Бабић Б., Јанић J. Сопронова печатња. Бања Лука, 2016. С. 32-37. 
ного австрийского публициста Густава Гейне. В 1851 г. переселился в Земун и открыл там типографию. И, наконец, в 1865 г. принял предложение от османских властей и переехал в Сараево.

Сопрон привез с собой все необходимое оборудование, наборы литер с кириллицей, латиницей и греческим алфавитом, а также наборщика Илию Томича из Белграда ${ }^{12}$. Турецкое правительство заключило с книгопечатником контракт на три года - предоставило ему бесплатное помещение, 38.000 гульденов ежегодно на производственные расходы и заработную плату в 2.000 гульденов ${ }^{13}$. Позже из Константинополя прибыл наборщик Кадри-эфенди Цариградлия, который привез литеры с арабицей ${ }^{14}$ (в Османской империи использовалось арабское письмо). Турецкие наборщики получали жалованье от правительства, а сербским платил сам Сопрон. Помимо печатания книг и газет он обучил своему ремеслу нескольких местных жителей: Йову Петровича, Ахмеда Зилждича, Стеву Стояновича и Ристу Чайкановича. Через полгода работы типография была выкуплена османскими властями у Сопрона за 600 дукатов и стала именоваться вилайетской ${ }^{15}$. В ее штат входили директор, два наборщика, четыре помощника, переводчик и разносчик газет ${ }^{16}$.

Местные власти дали разрешение Сопрону на издание своей неправительственной газеты. Так, 7 апреля 1866 г. в свет вышло первое периодическое издание Боснии - «Боснийский вестник» («Босански вјестник») ${ }^{17}$. Он печатался еженедельно (каждый четверг, а затем каждую субботу) до апреля 1867 г. Всего вышло 52 номера ${ }^{18}$. Первый выпуск начинался со стихотворения, посвященного Осман-паше. Материалы публиковались на вуковой кириллице ${ }^{19}$. В каждом номере было по восемь страниц.

В газете были следующие рубрики: местные и зарубежные известия, новости торговли, интересные факты, смесь, объявления. «Боснийский вестник» публиковал вилайетские законы ${ }^{20}$. Таким образом, местное население впервые смогло прочесть их на родном языке. Переводы с турецкого осуществлял учитель сербской школы из г. Приеполе Милош Мандич $(1843-1900)^{21}$. Под псевдонимом иеромонах Теофил Петранович печатал

12 Ademović F. Prve novine i prvi novinari u Bosni i Hercegovini. S. 18; Бабић Б., Jанић J. Coпронова печатња. С. 28-29.

13 Донесения об этом поступали в Святейший Синод. См.: Российский государственный исторический архив (РГИА). Ф. 797. Оп. 36. Отд. ІІ. Стол 3. Д. 36. Л. 3-5.

14 Ademović F. Prve novine i prvi novinari u Bosni i Hercegovini. S. 18.

15 Ibid. S. 20.

16 Ibid. S. 19.

17 Cм.: Kruševac T. Bosansko-hercegovački listovi u XIX veku. S. 27-40.

18 Сохранилось лишь 26 номеров.

19 Вукова или сербская кириллица - азбука, разработанная в начале XIX в. для сербскохорватского языка Вуком Караджичем на основе герцеговинского диалекта.

20 См., например: Босански вјестник. 1866. № 4, № 5, № 8-10.

21 Милош Мандич (1843-1900) - родился в Бихаче, в разные годы учился в Винковцах, Сремских Карловцах и Белграде. Изучал право, овладел немецким, французским, италь- 
народные песни Боснии и Герцеговины учитель сараевской школы Боголюб Петранович ${ }^{22}$. С изданием также сотрудничал писарь и мувекит ${ }^{23}$ мечети Гази Хусрев-бега в Сараеве Салих Сидки-эф. Хаджихусеинович (1825-1888). На страницах «Боснийского вестника» ${ }^{24}$ Он начал публиковать труд об османских управленцах в Боснии ${ }^{25}$.

«Боснийский вестник» и самого Сопрона подвергали критике сербы Княжества и хорваты. Сербы были недовольны употреблением на страницах газеты термина «боснийский язык», а хорватам не нравилось использование в ней кириллицы» ${ }^{26}$. И те и другие обвиняли книгопечатника в туркофильстве 27 . Вопрос о взаимоотношениях Сопрона с османскими властями остается неясным. В апреле 1866 г. он вернулся в Земун, но и после этого некото-

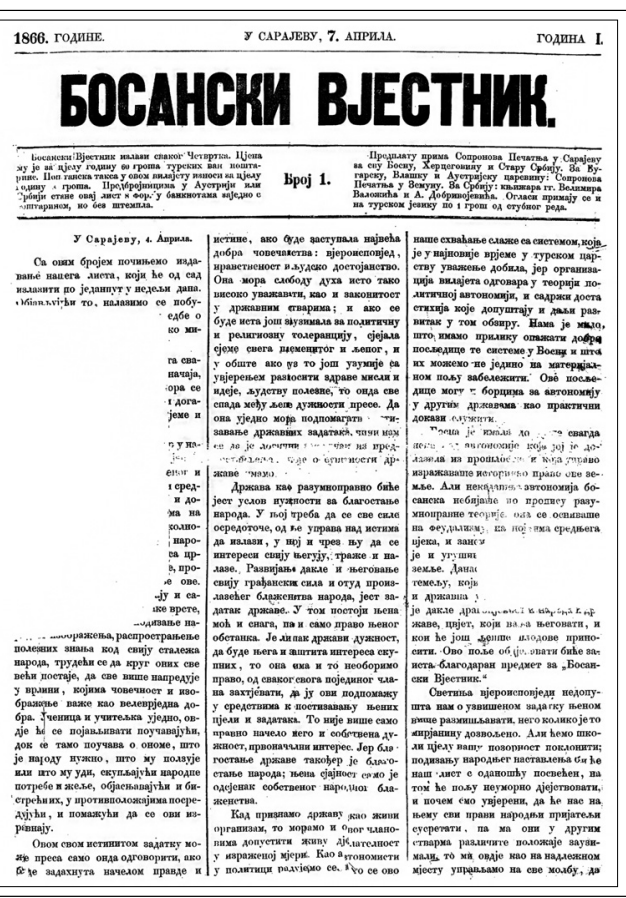

Боснийский вестник рое время продолжал выпускать газету.

Довольно быстро в Боснии появилась и вторая газета. В № 4 «Боснийского вестника» за 1866 г. сообщалась следующая новость: «Давно ожидаемые литеры с турецкими буквами прибыли в Брчко из Константинополя вместе с турецким наборщиком Кадри-эфенди, и в скором времени, как бу-

янским и турецким языками. Несколько лет был учителем сербской школы в местечке Нова Варош (Приеполе), затем перебрался в Сараево для работы в типографии. До оккупации Боснии и Герцеговины (1878 г.) был официальным переводчиком боснийских газет, редактировал первые учебники для сербских школ в Боснии и Герцеговине. После оккупации продолжал работу в редакциях различных изданий, был чиновником. Является автором работы «Турцизмы в Боснии и Герцеговине» (1895). См.: Босанска вила. 1900. № 21. С. 289-291; Kruševac T. Bosansko-hercegovački listovi u XIX veku. S. 29, 42-45; Ademović F. Prve novine i prvi novinari u Bosni i Hercegovini. S. 51, 105-107; Бабић Б., Јанић J. Сопронова печатња. С. 58-61.

22 См., например: Босански вјестник. 1866. № 3; № 9-13.

23 Мувекит отслеживал закат солнца для того, чтобы точно определить время молитв, а также отвечал за настройку лунных часов сахат-кулы.

24 Босански вјестник. 1867. № 11-12. Эти номера газеты не сохранились. См.: Kruševac T. Bosansko-hercegovački listovi u XIX veku. S. 30.

25 Работа не была напечатана полностью, так как газета прекратила существование. Позже, полная версия труда переиздавалась несколько раз. См.: Muvekkit Salih Sidki Hadžihuseinović. Povijest Bosne. Knj. 2. Sarajevo, 1999.

26 См., например: Босански вјестник. 1866. № 4. С. 26-27.

27 Kruševac T. Bosansko-hercegovački listovi u XIX veku. S. 39. 
дут доставлены еще некоторые вещи из Оршовы (город в Румынии. - К.M.), начнется выпуск официальной газеты "Босния" на турецком и боснийском языках, выхода которой с нетерпением ожидают во всем вилайете; набралось уже более 1.000 подписчиков» ${ }^{28}$.

Официальная вилайетская газета «Босния» («Босна») ${ }^{29}$ вышла на 40 дней позже «Боснийского вестника», в мае $1866 \Gamma^{30}$ Российский консул в Сараево Евграф Романович Щулепников (1858-1868 гг.) писал послу в Константинополе Николаю Павловичу Игнатьеву: «На прошедшей неделе вышел первый номер здешней официальной газеты на турецком и сербском языке под названием “Босна”. Он был полон похвал султану за устройство здесь типографии и не содержал в себе решительно ничего заслуживающего внимания» ${ }^{31}$.

Газета выходила один раз в неделю на четырех страницах и была двуязычной, - печаталась на османском ${ }^{32}$ и боснийском (сербской кириллице) языках. На страницах издания публиковались новости вилайета и Османской империи, а также иностранные известия, тексты законов и пояснения к ним. Главными редакторами в разное время были Сарайлия Мустафа Рефет-Имамович (1866-1868 гг.), Мехмед Шачир Куртчехаич (1868-1872) и Салих Биоградлия (1872-1878 гг.) 33 . Основными источниками служили газеты, издававшиеся в Константинополе. Материалы приходили почтой и телеграфом (Сараево - Нови-Пазар - Константинополь), которые появились в Боснии в 1860-е годы. Перевод статей и сообщений с османского языка осуществлял Милош Мандич. Всего за 13 лет вышло 636 номеров. В последнем, от 18 июля 1878 г., сообщалось, что австро-венгерское консульство в Сараеве объявило о готовности армии монархии Габсбургов перейти в Боснию и Герцеговину, что и произошло 29 июля.

С декабря 1868 по 1872 гг. по четвергам, затем по субботам выходило еженедельное литературно-политическое издание вилайета «Сараевский цветник» («Сарајевски цвјетник»), которое также было двуязычным (всего вышло 170 номеров) ${ }^{34}$. Первые выпуски газеты печатались на бумаге желтого цвета - поэтому за ней закрепилось название «желтая газета».

28 Босански вјестник. 1866. № 4. С. 26-27.

29 Ibid. S. 41-49.

30 Подробнее об издании см.: Ademović F. Prve novine i prvi novinari u Bosni i Hercegovini. S. 49-61.

31 Архив внешней политики Российской империи (АВПРИ). Ф. 180. Посольство в Константинополе. Д. 2328. Л. 35 об. Копии материалов из АВПРИ были получены автором статьи в архиве Отдела истории славянских народов Юго-Восточной Европы в Новое время Института славяноведения РАН.

32 Османский язык (osmanlica) - период развития турецкого литературного языка XV середины XIX вв. См.: Грунина ЭА. Учебное пособие по османско-турецкому языку. М., 1988; Гузев В.Г. Староосманский язык. М., 1979; Недков Б. Османо-турска дипломатика и палеография. Т. 1. София, 1972.

33 Kruševac T. Bosansko-hercegovački listovi u XIX veku. S. 42.

34 Пејановић Ђ. Штампа Босне и Херцеговине 1850-1941. С. 43-44; Kruševac T. Bosansko-hercegovački listovi u XIX veku. S. 50-62; Dizdar S. Bibliografija sarajevskog cvjetnika: prilog povijesti knjige. 
Главным редактором газеты был директор вилайетской типографии и официальный переводчик с турецкого Мехмед Шачир Куртчехаич 35 . Он же являлся основным автором статей. Осенью 1871 г. Мехмед Шачир путешествовал месяц по вилайету и подготовил серию репортажей о разных уголках Боснии и Герцеговины. Издание было нацелено на поддержку всех начинаний и политики османских властей. В своих заметках Куртчехаич активно полемизировал с сербскими («Видовдан», «Млада Србија», «Глас народа», «Јединство») ${ }^{36}$ и черногорской («Црногорац») ${ }^{37}$ газетами, а также с изданиями славян Австро-Венгрии («Застава», «Панчевац», «Народни лист», "Pozor" и др.) ${ }^{38}$. На страницах «Сараевского цветника» много писалось о сербских экспансионистских планах по отношению к Боснии, и поэтому в княжестве Сербия он был запрещен ${ }^{39}$.

Основная задача газеты заключалась в просвещении народа, борьбе с невежеством и суевериями. Помимо внутренних и иностранных известий, появилась постоянная рубрика с медицинскими советами, которую вел военный врач из Сараева Вели-бег (венгр Бечлия Галл) ${ }^{40}$. В своих статьях он рассказывал об основах оказания первой помощи в экстренных случаях, о необходимости соблюдения диеты после рождения детей, лекарствах, которые рекомендуется принимать весной, а также подробно информировал о таких болезнях, как сифилис, корь и ангина ${ }^{41}$. «Сараевский цветник» также уделял большое внимание проблемам развития сельского хозяйства и торговли ${ }^{42}$. В нем давались советы по разведению скота и засеву полей, сообщалось о последних крупных торговых операциях в вилайете.

Выпуск «Сараевского цветника» прекратился после кончины главного редактора Мехмеда Шачира Куртчехаича в 1872 г. Он и по сей день считается одним из самых значимых журналистов в истории Боснии.

35 Мехмед Шачир Куртчехаич (1844-1872) - родился в местечке Бело Поле в семье кади. Самостоятельно овладел турецким языком. Рано поступил на государственную службу. Был писарем в различных государственных учреждениях в городах Плевле и Нови-Пазар, затем переехал в Сараево. Являлся главным редактором газет «Босния» и «Сараевский цветник». В 1869-1872 гг. - директор вилайетской типографии. Являлся официальным переводчиком османских властей в суде, входил в состав вилайетской скупщины, с 1872 г. градоначальник Сараева. В июле 1872 г. отправился в Вену поправить здоровье, но в сентябре скончался от туберкулеза. Подробнее см.: Kruševac T. Bosansko-hercegovački listovi u XIX veku. S. 50-52; Ademović F. Prve novine i prvi novinari u Bosni i Hercegovini. S. 115-117; Dizdar S. Prvi Bošnjački novinar: Mehmed Saćir Kurtćehajić (1844-1872). S. 60-67.

36 См., например: Сарајевски цвјетник. 1870. № 9; 1872. № 43, № 47, № 50.

37 См., например: Сарајевски цвјетник. 1871. № 35.

38 Ademović F. Prve novine i prvi novinari u Bosni i Hercegovini. S. 70.

39 Kruševac T. Bosansko-hercegovački listovi u XIX veku. S. 52.

40 Первые медицинские учреждения в Боснии появились только в 1866 г. - заработали госпиталь, предназначенный исключительно для военнослужащих турецкой армии, и больница на 40 мест для гражданских лиц. Они принимали представителей всех вероисповеданий и национальностей. Лечение было бесплатным.

41 Сарајевски цвјетник. 1870. № 1-5, № 10, № 12-16, № 18-21, № 23-25, № 28, № 29 , № 31, № 34-42, № 44, № 45.

42 См., например: Сарајевски цвјетник. 1869. № 7, № 17, № 43; 1870 . № 3, № 41. 
После отделения Герцеговины от Боснийского вилайета в 1876 г. часть оборудования вилайетской типографии была перевезена в город Мостар ${ }^{43}$. Здесь начали выпускать еженедельную официальную газету «Неретва» ${ }^{4}$. Она также была двуязычной. Предположительно вышло около 40 номеров, сохранилось лишь четыре ${ }^{45}$. Главным редактором был Мехмед Хулуси. (1843-1907) ${ }^{46}$. На страницах издания публиковались внутренние и иностранные известия, много внимания уделялось вопросам образования. По своей структуре «Неретва» походила на газету «Босния».

На страницах боснийских газет звучала и тема России. К сожалению, нет возможности ознакомиться с материалами всех выпусков вышеназванных изданий. На основе библиографии «Сараевского цветника», составленной боснийской исследовательницей С. Диздар ${ }^{47}$, скомпонована следующая таблица:

\section{Упоминания о России}

на страницах газеты «Сараевский цветник» в 1868-1872 гг.

\begin{tabular}{|c|c|c|c|c|c|c|c|}
\hline \multirow{2}{*}{ год } & \multicolumn{7}{|c|}{ рубрика } \\
\cline { 2 - 8 } & $\begin{array}{c}\text { статьи } \\
\text { и } \\
\text { заметки } \\
\text { странные } \\
\text { известия }\end{array}$ & $\begin{array}{c}\text { вилайет- } \\
\text { ские } \\
\text { известия }\end{array}$ & $\begin{array}{c}\text { внутрен- } \\
\text { ние } \\
\text { известия }\end{array}$ & $\begin{array}{c}\text { новейшая } \\
\text { почта }\end{array}$ & $\begin{array}{c}\text { объяв- } \\
\text { ления }\end{array}$ & разное \\
\hline 1868 & 1 & 0 & 0 & 1 & 1 & 0 & 0 \\
\hline 1869 & 4 & 4 & 3 & 6 & 1 & 0 & 0 \\
\hline 1870 & 11 & 12 & 5 & 1 & 0 & $3^{48}$ & 0 \\
\hline 1871 & 20 & 16 & 4 & 1 & 0 & 0 & 1 \\
\hline 1872 & 1 & 13 & 4 & 1 & 0 & 0 & 0 \\
\hline \multirow{2}{*}{ всего: } & 37 & 45 & 16 & 10 & 2 & 3 & 1 \\
\cline { 2 - 9 } & & & $\mathbf{1 1 4}$ & & & 0 \\
\hline
\end{tabular}

Чаще всего использовались новости, взятые из константинопольских периодических изданий. Реже встречаются статьи, написанные журналистами из Боснии. К примеру, автором некоторых таких заметок был дабробосанский митрополит Дионисий II (1868-1871 гг.). Он использовал

43 Ademović F. Prve novine i prvi novinari u Bosni i Hercegovini. S. 83

44 Kruševac T. Bosansko-hercegovački listovi u XIX veku. S. 63-65.

45 Ademović F. Prve novine i prvi novinari u Bosni i Hercegovini. S. 84.

46 После австро-венгерской оккупации Боснии и Герцеговины Мехмед Хулуси выпускал в Сараеве газеты "Vatan" и "Rehbar" на турецком языке.

47 Dizdar S. Bibliografija sarajevskog cvjetnika: prilog povijesti knjige. S. 87-244.

48 Объявления о продаже российским консульством лошади. См.: Сарајевски цвјетник. 1870. № 17-19. 
псевдоним Любомир Босанчич. В большинстве его статей критикуется политика России в Боснии и Герцеговине, труды Славянского комитета и российских консулов на ниве просвещения православного населения вилайета. Заголовки этих работ говорят за себя: «О русском серболюбии и сербском руссолюбии» ${ }^{49}$, «О русско-сербской политике» ${ }^{50}$, «Нужны ли нам связи с Россией?»51.

В боснийских изданиях Российская империя предстает в негативном свете, как угнетательница разных народов - активно освещались польский ${ }^{2}$ и еврейский ${ }^{3}$ вопросы. Большое внимание уделялось деталям военной реформы в России ${ }^{54}$. Помимо этого, встречаются и анекдотичные упоминания. К примеру, в одном из номеров «Боснийского вестника» сообщалось следующее: «В России, за исключением севера Сибири, люди, живущие 130-150 лет, - нормальное явление. Один путешественник рассказал, что однажды в деревне встретил старика восьмидесяти лет, который горько плакал: “Когда я спросил его, почему он плачет, тот ответил, что его наказал отец. - Не может быть! Неужели твой отец ещё жив? - Жив. - А за что тебя наказал? - За то, что я деда выпустил, тот упал"» 55.

Присутствует также несколько сообщений о российских консулах и объявления от работников консульств. К примеру: каваз (охранник) консульства продает две лошади ${ }^{56}$; консул в Сараеве Кудрявцев получил орден Меджедие 3-ей степени ${ }^{57}$, орден Св. Станислава 2-ой степени и орден персидского шаха Шири-Хуршид ${ }^{58}$, Кудрявцев отбывает в отпуск ${ }^{59}$; опубликована благодарность Кудрявцеву за пожертвование денежных средств (около 40 пиастров) для одной из школ Боснии ${ }^{60}$; напечатано известие о назначении на должность российского консула в Мостаре Н.А. Иларионова и переводе оттуда в Персию В.В. Безобразова ${ }^{61}$. Следили боснийские газеты и за судьбой российских дипломатов, которые окончили службу в вилайете. Так встречается сообщение о том, что бывшему российскому консулу в Сараеве А.Ф. Гильфердингу (1857-1858 гг.) пожаловано имение ${ }^{62}$. На стра-

49 Сарајевски цвјетник. 1870. № 45.

50 Сарајевски цвјетник. 1870. № 46.

51 Сарајевски цвјетник. 1870. № 48.

52 См., например: Босански вјестник. 1867. № 41; Сарајевски цвјетник. 1868. № 1, 1869. № 21, № 23, № 26; 1870. № 16, № 25; 1871. № 4, № 9, № 12, № 13; 1872 . № 3, № 7, № 13 .

53 См., например: Сарајевски цвјетник. 1870. № 4, № 7; 1871. № 3, № 15, № 21.

54 См., например: Сарајевски цвјетник. 1871. № 39, № 40, № 43.

55 Босански вјестник. 1866. № 4. С. 32.

56 Босна. 1870. № 222; Сарајевски цвјетник. 1870. № 17-19.

57 Босна. 1874. № 405-406.

58 Сарајевски цвјетник. 1871. № 18.

59 Сарајевски цвјетник. 1870. № 20.

60 Сарајевски цвјетник. 1871. № 34.

61 Босански вјестник. 1866. № 23. С. 179.

62 Босански вјестник. 1866. № 18. С. 144. 
ницах «Сараевского цветника» можно найти объявление о готовности боснийского вали Сафвет-паши (1869-1871 гг.) оказать содействие в возвращении кредиторам долгов от бывшего российского консула Е.Р. Щулепникова ${ }^{63}$. Этот дипломат увлекался азартными играми. За свое пребывание в Сараеве он задолжал значительные суммы денег кавазам российского консульства Али-аге и Вели-аге 64.

Редакции газет активно сотрудничали с представителями всех вероисповеданий. К примеру, внештатными корреспондентами были дабробосанский митрополит Дионисий $\mathrm{II}^{65}$ и сараевский архимандрит Савва Косанович (1839-1903) ${ }^{66}$. Главная идея Осман-паши состояла в том, чтобы сделать боснийские газеты интересными и доступными для всех жителей вилайета, которых на страницах периодических изданий именовали боснийцами, а их родной язык - боснийским. Можно отметить тот факт, что качество материалов оставляло желать лучшего. В них публиковалось множество забавных, курьезных сообщений. Иностранные известия, курсы валют местные жители могли узнавать и ранее, выписывая газеты сербские и австрийские, но, наконец, у них появилась возможность знакомиться с новостями и законами своего вилайета. С 1867 г. боснийские власти запретили ввоз и распространение славянских газет из Австро-Венгрии и Сербии ${ }^{67}$. Таким образом, вилайетские периодические издания стали единственными доступными источниками информации. После оккупации Боснии и Герцеговины Австро-Венгрией многие сотрудники боснийских газет стали работать в редакциях периодических изданий монархии Габсбургов.

\section{ЛИТЕРАТУРА}

Бабић Б., Јанић J. Сопронова печатња. Бања Лука, 2016.

Гильфердинг А.Ф. Босния, Герцеговина и Старая Сербия // Собрание сочинений А. Гильфердинга. Том третий. Босния и Герцеговина и Старая Сербия. СПб., 1873. С. 1-278.

Мельчакова К.В. Осман-паша в погоне за прогрессом. К проблеме конструирования боснийской нации в Османской империи в 1861-1869 гг. // Вынужденное соседство - добровольное приспособление в дипломатических и межнациональных отношениях в Центральной, Восточной и Юго-Восточной Европе XVIII-XXI вв. Сборник статей. М.; СПб., 2017. С. 269-284.

Милош Мандић, српски новинар // Босанска вила. 1900. № 21. С. 289-291.

Пејановић Ђ. Штампа Босне и Херцеговине 1850-1941. Сарајево, 1949.

63 Сарајевски цвјетник. 1869. № 26.

64 См.: Отдел письменных источников Государственного исторического музея (ОПИ ГИМ). Ф. 347. Оп. 1. Ед. хр. 79.

65 Сарајевски цвјетник. 1870. № 43-46, № 48.

66 Сарајевски цвјетник. 1869. № 48; 1870 . № 31.

67 Из донесения российского консула в Мостаре Н.А. Иларионова к Н.П. Игнатьеву. См.: АВПРИ. Ф. 180. Посольство в Константинополе. Д. 2053. Л. 2-2 об. 
Ademović F. Prve novine i prvi novinari u Bosni i Hercegovini. Sarajevo, 1999.

Dizdar S. Bibliografija sarajevskog cvjetnika: prilog povijesti knjige. Sarajevo, 2017.

Dizdar S. Prvi Bošnjački novinar: Mehmed Šaćir Kurtćehajić (1844-1872) // Bosniaca. Časopis Nacionalne i univerzitetske biblioteke Bosne i Hercegovine. God. 17. Br. 17. (decembar 2012). S. 60-67

Koetschet J. Osman Pascha, der letzte grosse Wesier Bosniens und seine Nachfolger. Sarajevo, 1909.

Kruševac T. Bosansko-hercegovački listovi u XIX veku. Sarajevo, 1978.

СПИСОК ИЛЛЮСТРАЦИЙ

1. Топал Шериф Осман-паша.

2. Газета «Боснийский вестник».

3. Газета «Босния».

4. Евграф Романович Щулепников.

5. Николай Павлович Игнатьев.

6. Мехмед Шачир Куртчехаич.

7. Газета «Сараевский цветник».

8. Газета «Неретва». 